\title{
Exploring accountability discourses and practices in the Spanish aid system
}

\section{Alejandra Boni, Jordi Peris, Rosemary McGee, Miriam Acebillo- Baque and Andrés Hueso}

Final version of a paper which was published in 2014 in the Journal of International Development, 26, 541-555.

\begin{abstract}
This article aims to explore the different accountability discourses of the various actors in the Spanish international aid system and to examine them in light of the various theoretical interpretations of development accountability. The conclusions reached suggest a technical and financial accountability model, largely isolated from international debates where political and social issues are at the core of the concept. Although this can be explained by a range of factors which are specific to the Spanish aid system, there are also interesting tendencies that are deepening a new understanding and practice of the idea.
\end{abstract}

Keywords: aid effectiveness; accountability; Spanish aid system; bilateral aid; NGDOs; decentralised cooperation

\section{INTRODUCTION}

This article presents the findings of a study carried out by a multidisciplinary research team between June 2008 and November 2009. The aim of the study was to explore the different accountability discourses of the various actors in the Spanish international aid system and to examine them in light of the various theoretical interpretations of accountability in relation to development.

The project's objectives are framed by the international debates on aid effectiveness, of which the most visible account is reflected in the processes of Paris/Accra fostered by the Organization for Economic Cooperation and Development (OECD). In this context, to understand what quality of aid implies inevitably entails talking about accountability. Discussing the quality of Spanish overseas development assistance (ODA) has gained relevance as the country has become, in a relatively short time, one of the most important donors. ${ }^{1}$ Spain is also a point of reference in the context of the European Union because of its relationship with Latin America. However, important changes are still needed to

\footnotetext{
${ }^{1}$ Spain is the 6th largest donor in terms of absolute ODA volume and 11th when taking into account the amount of ODA over the national income.
} 
improve its policies and actions concerning accountability (Intermón Oxfam 2011). This is all the more challenging as its decentralised governance system adds complexity to accountability processes and mechanisms.

This article is structured as follows: the first part contains a description of accountability within the framework of the present aid effectiveness agenda and a brief description of the Spanish development aid system. The second part describes the approach adopted by the study and the methodology used. The third part deals with some interpretations of the meaning, actors, and mechanisms involved in accountability in international aid. The fourth part discusses the evidence as found by the study in relation to Spanish aid, and suggestions are made as to how to improve its accountability. The final section sums up our most salient findings and concludes.

\subsection{Paris DeclarationandAccountability}

In 2005, a hundred aid donor and recipient nations signed the Paris Declaration on Aid Effectiveness (PD), within a process set in motion by the Development Assistance Committee (DAC) of the OECD. These countries signed a commitment to 'take far-reaching and monitorable actions to reform the ways we deliver and manage aid' (OECD, 2005). For this, five working rules were established, the fifth of which referred to mutual account-ability. This was defined as both 'partner' (i.e. developing) and donor countries giving priority to increasing accountability and transparency in the use of development funds.

In the agreement signed in Accra in 2008, which followed the line of the PD, the term mutual accountability lost some of the prominence given to it in the PD. It did not figure in any of the main headings and was only mentioned in Paragraphs 19 and 31, in the latter to express gratitude to ECOSOC for its 'international dialogue and mutual responsibility'.

However, although the principle of mutual accountability may not have the same force as other principles of the PD, it can still be considered an essential part of understanding international aid, and although it is aimed principally at states, it can also have implications for non-governmental aid. Indeed, a demand for a mutual accountability that goes beyond donors and governments has been voiced by social platforms in and after the Paris/Accra process (Civil Society Voices for Better Aid, 2008; ISG, 2007).

\subsection{The Spanish Aid System}

Spain was a latecomer to the international development aid system. Unlike other donor countries, until 1979, Spain was considered by the World Bank to be a developing country with medium-high income. In 1983, at its own request, it ceased to have aid-recipient status (Tezanos, 2008: 39). In 1985, the SubDepartment of State for IberoAmerica was created, which changed its name in 
2004 to the Sub-Department of State for International Aid (SECI ${ }^{2}$ in Spanish) and is the principal organization for formulating Spanish inter- national aid policy. In 1988, the Spanish International Development Agency (AECID ${ }^{3}$ ) was founded as the implementing agency of national-level aid policy and coordinator of a network of 42 technical cooperation offices, mainly located in Latin America.

Also created in 1988 was the Planning and Evaluation Office, which in 2005 became the Directorate-General of Planning and Evaluation of Development Policies (DGPOLDE ${ }^{4}$ ). Its role consists of assisting the SECI to formulate, plan, monitor, and evaluate Spanish international aid policy. It also coordinates external relations with inter- national organizations such as the DAC and OECD. The DGPOLDE is responsible for drawing up policy documents on aid at the national (Spanish state) level, such as the national aid policy document, in Spanish the Plan Director, established by law in 1998 (the third Plan Director is now in force for 2009-2012), annual plans, strategy papers for individual countries, and operational plans (Meyer, 2007: 12).

In the first decade of the 21st century, Spain has played a leading role in global aid governance structures. In 2000, it signed the UN's Millennium Summit Declaration and between 2003 and 2008 took part in all the conferences organised by the DAC. In 2008, Spain devoted $0.45 \%$ of its gross domestic product (GDP) to overseas development aid (€4800 million), which was over $€ 1000$ million more than in 2007 and the largest sum ever spent by Spanish aid organizations (Ministerio de Asuntos Exteriores y Cooperación, 2009:8). Provisional DAC figures for aid in 2009 placed Spain seventh in the world among donor countries, with a total aid budget of $\$ 6.57$ billion (Development Cooperation Directorate, 2010).

Among the chief coordinating bodies for Spanish aid are the Development Aid Council and the Inter-Territorial Development Aid Commission. The former is an advisory body that brings together the principal actors involved in aid (civil society organizations, other social actors involved in aid, and representatives of the Spanish state). It was established in 1995 in response to mass social mobilization in favour of devoting $0.7 \%$ of GDP to international aid (Meyer, 2007: 15). This council put into action Law 23/1998, which regulates the objectives and workings of aid policy (Tezanos, 2008: 47).

The latter organization, the Inter-Territorial Development Aid Commission, testifies to the high degree of decentralisation of Spanish aid. It brings together representatives from the seventeen "autonomous communities" (the autonomously governed regions into which the Spanish state is divided), besides diputaciones or provinces (the next administrative division below the level of autonomous communities) and municipalities and local councils, which are all empowered to provide development aid in their own right to partners in Spain and the global south. The aid provided by the autonomous communities and more

\footnotetext{
${ }^{2}$ Secretaría de Estado de Cooperación Internacional.

${ }^{3}$ Agencia Española para la Cooperación Internacional al Desarrollo.

${ }^{4}$ Dirección General de Planificación y Evaluación de Políticas de Desarrollo.
} 
local levels of government (known in Spain as decentralised aid) in 2008 comprised $18.42 \%$ of bilateral ODA (Ministerio de Asuntos Exteriores y Cooperación, 2009).

Autonomous communities' and local governments' aid policy frameworks have instituted aid advisory councils as policy spaces to enable social participation in aid activities, in much the same way as the state Development Aid Council. They have also drawn up aid strategies or annual plans (Montiel, 2007: 75; Sánchez, 2007: 171).

Development non-governmental organizations (NGOs) are another important actor group in Spanish international aid. According to figures from the Spanish NGO Coordinating Body (comprising 87 development NGOs and 16 coordinating bodies from various autonomous regions), in 2007, Spanish NGOs obtained $€ 669$ million, 54.3\% of which came from public bodies and the rest from private sources (Coordinadora Estatal de Cooperación al Desarrollo, 2008: 20).

Spanish development NGOs are of diverse types. The oldest were created during Franco's dictatorship, and others appeared during the subsequent political transition as expressions of international solidarity. A very significant time for Spanish NGOs was during the popular demonstrations to demand that $0.7 \%$ of the GDP be devoted to international aid (1994-2000). During this period, the Law on International Development Aid was passed, and the NGO Coordinating Body's Code of Conduct was drawn up.

Our study on accountability discourses in the Spanish aid system took place within this crowded decentralised scenario. We faced a difficult challenge because exploring the Spanish aid system implies exploring not a single central administration, but 17 autonomous communities plus a large number of provincial and municipal organizations, besides countless NGOs that provide aid derived from public and private sources.

\section{APPROACH AND METHODOLOGY OF THE STUDY}

The study lay within an applied qualitative social research paradigm that situated its analysis firmly within the social and historical context in which it occurred and through which it is interpreted (Corbetta, 2003; Flick et al., 2004; Valles, 1996).

We therefore sought to access the perspectives of the different actors involved in the Spanish aid system to understand the different meanings they attach to the idea and practice of accountability. It therefore carries the premise that gathering information on the different actors' interpretations of accountability is a good way of understanding how this concept is taking shape within the context of Spanish aid and subsequently of formulating realistic proposals that the actors themselves would find useful when developing their policies.

Work was carried out in three basic stages. The first consisted of a desk-based 
review of the literature and critical debates on accountability in the development aid system. In the course of this review, we analysed what light the discourses of academics, donors, and NGOs shed on four key accountability questions, which draw closely on questions posed by Newell (2006) and Goetz and Jenkins (2005): (1) what is it and why is it necessary? (2) Who should account to whom? (3) How is accountability practised and by what means can control be exercised over power holders? (4) In what forums can it be expected and looked for?

This was followed by a stage of empirical research on Spanish participants, in the form of 37 in-depth semistructured interviews, representing all 32 organisations. Through these, we gathered the perspectives of (1) technicians and politicians from the state level (five interviews with AECID and DGPOLDE representatives), autonomous communities (six interviews with representatives of development policy units in the Valencian, Basque, and Catalan governments), and local administrations (four interviews with representatives of two major cities, Barcelona and Valencia, and two smaller towns, one in the province of Barcelona and another in the province of Valencia); (2) members of international, Spanish, and local development NGOs (seven NGOs); (3) private sector companies (one public company and one private); and (4) universities and different types of experts (10 representatives). Given the shape of the Spanish aid system, the sampling strategy took into account a vertical dimension (considering the different governance levels) and the plurality of actors at each level that participate in the ODA funding chain. The interviewees at each governance level were sampled due to their relevance and because they substantially con- tribute (by position, experience, or knowledge) to the Spanish accountability debate. ${ }^{5}$ The key consideration in sampling was not any kind of statistical representativity but an attempt to capture a representative spread of accountability discourses.

The formulation of the key research hypotheses or propositions was an iterative process. Four research propositions were initially formulated to direct researchers' attention, which were then reviewed after the literature review and refined even further after the interviews. From this mass of data, 25 variables were defined with which the qualitative empirical material was analysed using the HyperResearch software package. In the next sections, we give some of the key debates that emerged in the course of the literature review and which were subsequently used to guide discussion on accountability discourses in the Spanish aid system. These are generally gathered as crosscutting issues stemming from the universe of sources consulted. Wherever possible, we note whether an idea or debate pertains to a collective or individual actor.

\section{FRAMING THE ENQUIRY: MEANINGS OF ACCOUNTABILITY}

5 A complete Spanish version of the study can be seen at http://masterdesarrollo.upv.es/mppd/index.php?option=com_wrapper\&view=wrapper\&Ite mid=28 (retrieved 27 June 2011). 


\subsection{What Is Accountability and Why Is it Necessary?}

From a theoretical point of view, Goetz and Jenkins defined accountability as 'the relation- ship where $\mathrm{A}$ is accountable to $\mathrm{B}$ if $\mathrm{A}$ is obliged to explain and justify his actions to B, or if A may suffer sanctions if his conduct, or explanation for it, is found wanting by B' (Goetz and Jenkins, 2005:8).

This allows us to distinguish between two dimensions of accountability: answerability, which is both the obligation to give an answer and the right to obtain an answer, and enforceability, which is the capacity to demand an action and ensure that it is carried out and access to corrective (and punitive) measures when accountability fails (Goetz and Jenkins, 2005; Newell and Bellour, 2002).

The capacity to demand and exercise accountability therefore requires power. In academic discourses, it is assumed that accountability cannot be reduced to a purely technical perspective related to inspection and management systems (Eyben, 2008; Goetz and Jenkins, 2005; Newell, 2006), but it must be understood from the perspective of established power relation- ships. Here, it is interesting to note three of the most frequent sorts of barrier to accountability: vacuums or spaces reserved for those in authority and not subjected to accountability; bias, or practices that, although not illegal, do benefit privileged groups; and capture, either by elites or via illegal use of power such as vote buying or corruption (Goetz and Jenkins, 2005). In line with this, Eyben (2008) emphasised the 'relational' nature of accountability, stressing, rather than the actors themselves, the relationships between them, which are formed in ways reflective of power and conditioned by specific historical trajectories.

Academic commentators tend to situate accountability within the framework of democratic rights and duties, often with reference to rights-based approaches to development on citizenship, which emphasise citizens' capacity to claim their rights, accountability mechanisms, and the institutional capacity for designing and reporting on development (Piron, 2004). This is in contrast to the donor countries' point of view as expressed in the PD (OECD, 2005) and the Accra Agenda for Action (OECD, 2008), in which the concept of mutual accountability emerges as one of the key innovations for aid effectiveness and effectively crosscuts the rest of the PD principles (OECD, 2007:16). De Renzio and Mulley (2006) highlighted how the concept of accountability in the PD highlights answerability aspects, but not those of enforceability.

In the ambit of the development NGOs, the panorama is more diverse. Here, representation seems to be a fundamental question, and the opinion is that this should not be limited to the political sphere but extended to include social representation, as a constitutive element of any democracy (Peruzzotti, 2006). However, until quite recently, NGO account- ability focused on technical solutions that often failed to reflect the mission, values, and multiplicity of important relationships in which they were involved (Jordan and Van Tuijl, 2006: 6). Two contradictory tendencies stand out. On one hand, 'bringing the state back in' as a principal development actor favours a concept of accountability premised on the 'projection of credibility and the promotion of external (state) control'. On 
the other hand, seen from the perspective of rights-based approaches, NGOs contribute to democratic governance, so accountability is about 'balancing the multiple responsibilities to the many actors involved by different means, favouring harmonisation instead of regulation' (Jordan and Van Tuijl, 2006: 1213). At the field level, NGOs' accountability to those with whom they work generates inherent tensions (Harsh et al., 2010).

Among the leading international organisations and initiatives focused on accountability, certain ones stand out: Action Aid as a radical organizational transformation process (Chambers and Pettit, 2004:147; Jordan and Van Tuijl, 2006: 18); the Global Accountability Project (GAP) of One World Trust and its emphasis on transparency, participation, evaluation, and complaint-response mechanisms (Blagescu et al., 2005: 23); AccountAbility, which emphasises governance frameworks in the establishment of collaboration initiatives (Litovsky and Macgillivray, 2007: 15); the EURODAD network, which aspires to contribute an element of enforceability to mutual accountability (Hayes and Pereira 2008: 45); or the initiatives taken by leading international NGOs (ActionAid, Amnesty International, Greenpeace, Oxfam, among others) in subscribing to the INGO Accountability Charter. ${ }^{6}$

\subsection{Who Is Accountable to Whom?}

Accountability has traditionally been understood in terms of the means at citizens' disposal to control the behaviour of the state, encompassing vertical forms such as elections and horizontal forms such as mutual control among state bodies. However, the transformation and reconfiguration of relationships between citizens, the private sector, the state, society and international institutions within the context of globalisation point to the need to contemplate a wider range of actors in accountability processes (Goetz and Jenkins, 2005; Newell, 2006). The distinction made between an agent (the one obliged to give account, understood as an actor to whom power has been delegated) and a seeker (the one who has the right to demand accountability, being the legitimate source of the agent's power) is a useful one because it allows the roles of the different actors in the international aid system to be easily classified. The aid system is characterised not only by an increase of numbers of agents and seekers but also by an increase in related methods and areas in which accountability is demanded and offered and by the diversity of roles each actor can perform (Goetz and Jenkins, 2005).

Different types of accountability arise. Political accountability is related to representative democracy, and its principal actor is the state in its relations both with its citizens and between its own institutions. Social accountability originates from rights discourses and is about how citizen action redefines citizens' relationships with their political representatives and the state. Financial accountability is linked to the workings, results, and accounts of organizations and proclaims itself to be apolitical and technical. Civil account-ability is the

\footnotetext{
${ }^{6}$ Available at http://www.ingoaccountabilitycharter.org/ (retrieved 27th June 2011).
} 
expression of active citizens, is not directed so much at state institutions, and involves different types of activism (Newell, 2006; Newell and Bellour, 2002).

These kinds of strategy can generate either what Newell (2006) called active account- ability, which is continually negotiated and assumes both the right and the capacity to make demands, or passive accountability, in which the initiative lies with those who have been given the authority to act in the name of others.

In contrast to this academic view of accountability, donors' discourses are based on a strongly state-centred perspective. The mutual accountability of the PD refers mainly to relations between donor countries and partner countries (Droop et al., 2008:1). Although this view was further refined in the Accra Agenda for Action (OECD, 2008), it is still a political and financial type of accountability, according to Newell's classification (2006), which sug- gests an ambiguous relationship with citizens (Wood et al., 2008) and makes no reference to the fact that there are actors that actively seek accountability or have a right to claim it.

In contrast, the civil society actors organised around the Paris process opt for a rights-centred approach as the regulatory and organizational framework for accountability within the aid system (Eyben, 2008:12) and demands that mutual accountability should go beyond donors and governments (Civil Society Voices for Better Aid, 2008; ISG, 2007). However, the debate is restricted to a group of openly political development NGOs (Bendell, 2006:78) and even the position of the GAP appears to be on the passive side insofar as it only requires NGOs to account for themselves.

\section{EXPLORING MEANINGS AND ACCOUNTABILITY PRACTICES IN THE SPANISH AID SYSTEM.}

\subsection{How Do Spanish Actors in International Aid Understand Accountability?}

By interviewing participants in both non-governmental and government aid organizations (state, autonomous, and local), we gathered evidence concerning their ideas on the nature, range, and significance of this concept.

A large majority of the actors understand accountability to mean accounting for them- selves and being transparent in relation to the use of the funds obtained, tending to limit the concept to auditing or financial control. Some also include the idea of impact or evaluation, considering that accountability should include explaining not only how money has been spent but also what results have been obtained. Consistent with this view, quality management systems are cited as accountability mechanisms, evincing a clear prevalence of what the literature calls financial accountability. Some government actors, trying to live up to international standards and widen the prevailing concept of accountability, speak of mutual responsibility vis-a-vis southern countries but in general are referring more to accountability exercised through political institutions than social or civil accountability. 
The rationale for accountability encountered among our respondents is fundamentally legal, and in certain cases ethical, but nowhere is power mentioned as a key element in accountability relationships. Accountability is considered as a relationship-management problem, but when its mechanisms are examined, no reference is made to reviewing the power relationships established between those who may demand accountability and those whose duty it is to provide it.

On the question of which actors are involved in accountability relationships, there was a general consensus that accounts should be rendered to those who provide funding. Mention was often made of the obligation and need to improve accountability to northern citizens and to their representatives: parliaments, councils, etc. The NGOs included their members and sponsors when listing who was involved in accountability relationships. However, in most cases, accountability to the southern partners and to those who receive the aid was not mentioned.

Another objective of our research was to determine which elements in the Spanish con- text might shape the concept of accountability held by the interviewees. In relation to this, we identified three important elements: decentralisation, dependence on public funds, and the existing spaces for reflection.

Concerning decentralisation, there is a wide diversity in Spanish development aid sys- tem, and both regional governments and local councils express a preference for relation- ships between actors in the system to be non-hierarchical and horizontal networks. Thus, although at the national level aid given by autonomous communities is considered to usurp positions that rightly belong to the state, the actors providing decentralised aid are legitimated both by legal frameworks and by the backing they receive from private citizens.

As for the non-governmental sector, its independence and capacity to demand account- ability from the state and autonomous community governments are somewhat restricted by its reliance on public funds. Also, because there has been no debate on which kind of accountability and which mechanisms are most appropriate for this sector, its demands have been limited to financial and technical matters. Because there are no standardised procedures among the different public sources of funds, this has meant considerable work for the NGOs. In relation to the above, it should be remembered that the public administrations (especially the central, state, administration) constitute a de facto regulatory organism, although they are made up of executive and not legislative or judicial bodies. This means that even if they do not have the backing of regulations or laws, the public development aid bodies have the most say in establishing criteria for determining the quality of the aid projects undertaken by the NGOs. The dependence of these organizations on public funds presents challenges as soon as wider concepts of accountability are considered.

Another element analysed in the Spanish aid context was its organisational culture and the (few) possibilities for reflection available to the actors. We had already assumed that both elements limited the concepts of accountability held 
by the interviewees. In fact, the evidence gathered by the study shows that processes of improvement and debate around accountability are correlated with advancing maturity, the gradual acquisition of a learning-oriented culture of evaluation (and self-evaluation, still much more incipient), and participation in international debates and forums.

\subsection{What Are the Accountability Practices in Use?}

The Spanish aid system broadly speaking practices financial accountability. However, when political accountability is examined, there is a certain amount of friction between the different aid actors as a result of the decentralised and non-hierarchical Spanish model.

The autonomous communities interviewed maintain that accountability is expected and provided from the autonomous regions to the central government, but not in the opposite direction. Direct accounting to citizens from the different public bodies is very scarce and weak.

Although certain actors do incorporate elements of social accountability in their dis- course by mentioning the societies as well as governments of partner countries, this is not reflected in practice, as the mechanisms are either nonexistent or scarcely defined. Government aid actors speak of social accountability mainly with reference to Spanish society and information provision, that is, forms involving very little active participation or involvement by citizens. People's participation or involvement is made possible and is recognised in the form of multi-stakeholder bodies such as aid councils, in which their role is limited to being consulted or simply being informed.

Another generalised practice is to understand accountability simply as transparency, assuming that being visible is the same as giving adequate account, be what they may the underlying processes. Accountability is also confused with information provision. In such cases, information provision appears almost a public relations exercise: some of those interviewed complained that information is often given out so that the organization involved can 'give itself a pat on the back'. In partner countries, accountability in the form of the transparency of aid actions is questioned on the basis that it might undermine the country's government and institutional standing by showing it in a bad light.

The actors interviewed broadly concur that there is a need to both widen the accountability discourse and improve practices. In the specific case of the Spanish International Development Agency, the DGPOLDE, and the organizations from the autonomous regions that were interviewed, it was acknowledged that civil society is given little account. It was also emphasised that there are strong asymmetries affecting accountability relationships and that, although financial accountability is largely taken on board and performed, at least in the public administration, the issue of accountability should be taken further. 


\subsection{What Barriers Exist?}

Based on the evidence we gathered, it appears that considerable accountability challenges are inherent to the decentralised Spanish system, affecting especially the accountability of state actors. As previously stated, friction exists between the different aid-providing actors in Spain because of their functioning within a decentralised and non-hierarchical model. It was also clear that the decentralised Spanish political system produces gaps in accountability in the sense that, as maintained by the autonomous community government actors inter- viewed, they are accountable to the state government but the state government is not accountable to them. The decentralised model generates dynamics in which the autonomous communities and local entities have legitimate grounds for demanding accountability from the central government and passing it on to their inhabitants and taxpayers.

Interesting reflections arose on state coordinating bodies, such as the Development Aid Council and the Inter-Territorial Aid Commission. Despite their potential, they are not always capable of delivering accountability. The interviewees stressed three points: (1) dysfunctions due to their dual nature as organs of both inter-ministerial coordination and "expert groups", (2) the NGO members' financial dependence on government funds, and (3) strengthening of bilateral relations between government actors and development NGOs in these spaces, with scant concern for creating or using more open and multilateral spaces.

Private interests, clientelism, and self-interested use of power differences between actors obstruct effective accountability in bodies such as the aid councils and constrain the improvement of accountability mechanisms.

In the ambit of development NGOs, the coordinating bodies function as a control element in that they can improve the proper and effective use of resources. However, the frag- mentation, proliferation, and competition between NGOs make it difficult to coordinate diverse interests in collective initiatives.

Worthy of note was the conflict between aid and other objectives, such as the international image of the government or commercial or economic agenda. The study shows that high-visibility official development aid projects, promoted with an eye to political advantage, involves investing in areas that are not very strategically important to the partner country but are high profile for the donor.

Finally, we detected the existence of technical barriers that prevented the improvement of accountability, such as a lack of financial resources and the fact that the basic unit of accountability is basically and almost exclusively the development project. This makes it difficult to widen debates to embrace the role of aid in development processes, which are complex, integral, and happen over long periods.

The dependence on public funds to finance projects stands out as a significant constraint. There is no incentive - in fact, there are negative incentives - on the 
part of those who receive public funds (Spanish NGOs) to criticise or question the discourses and practices of the government which (co-)finances them. The same factor limits the plurality of perspectives and preferences of the sector in general.

The general scarcity of spaces for reflection within the organizations and institutions constitutes a final constraint. None of the leading international actors in the discourse and practice of accountability have achieved this position without consciously and systematically creating spaces and time for profound and self-critical reflection that allows them to think beyond day-to-day mindsets and procedures and enables them to see that things can be done differently.

\subsection{Change Processes Under Way: Scope for Improved Accountability}

Despite the limitations we found in conceptions and practices of accountability, we identified certain change processes in the Spanish aid system that directly relate to some of the most important factors in how accountability is conceived and practiced.

The first clear tendency is the will to bring Spanish aid in line with the standards set in international declarations, a logical consequence of which is to bring southern actors into view as actors entitled to accountability. However, although the concept of mutual accountability contained in the PD has the potential to put this question on the agenda, in practice, the accountability that is provided even by core PD signatories is vitiated by the power relationships inherent in the international aid system. It is therefore important that the actors in this system be aware of these barriers and set in motion critical review procedures that address head-on the power relationships between northern and southern partners.

Second, some actors consider that the quality of relationships is starting to be recognised as a strategic element in aid effectiveness. In this area, a decisive step toward authentic mutual accountability would be to explicitly step beyond mere technical and financial accountability to introduce and promote elements of political, social, or civil accountability as well. A key locus where this sort of change cries out to be introduced is in the calls for co-financing applications, issued by public bodies, which are the principal vehicle via which NGDOs obtain funds. If these calls explicitly required bids to address accountability concerns in a broader way, incorporating aspects of social and political accountability and aid effectiveness that go well beyond narrow "value-formoney" criteria, this would have an immediate multiplier effect. Similarly, a change in policy toward co-financing larger long-term projects instead of small, short-lived projects and toward allocating funds on the basis of bidding organizations' capacity and experience would help reinforce good partnership and mutual trust between northern NGOs and their southern partners.

We observed a tendency to classify quality control systems as accountability mechanisms, which attests to a shift from accountability as merely financial control 
to accountability as relating also to objectives and results. This shift would be favoured by introducing into quality debates some reflection on process indicators and on how to assess the quality of aid relationships as inherent aspects of quality control. Today's dominant results-based management framework could thus be used to bring in accountability in a way that emphasises not only material and visible results but also the relationships among the actors involved in development processes.

There has also been a change in the importance attached to evaluation and a growing realization of the importance of systematizing experiences, developments which could and should be accompanied by a burgeoning culture of learning within organizations. Both within the NGOs themselves and among other public and private actors, much could be achieved by promoting evaluations designed not for inspection and control purposes, but for encouraging reflection and the questioning of organizational practices and values in different working contexts.

The research has highlighted the potential role of coordination spaces in generating accountability and reconsidering its meaning. NGO coordinating bodies should not only require accountability from governments, but should also pause to consider what the term means within the NGO world: who therein should be obliged to account, to whom, and how. It is especially important that this debate be extended to small NGOs with no representation in these coordinating fora. In the case of the official aid coordinating bodies of the central administration, there is an urgent need to reconsider their workings and reflect on how they can be transformed into mutual accountability spaces.

The need for legitimacy and credibility is increasingly evident to aid actors of the kinds we interviewed. For this, it is essential to improve their transparency, improving communication and access to information and opening them up better to effective public scrutiny.

These potentially promising changes, however, need to be weighed up in light of the strong evidence we found of a Spanish political culture that tends to shy away from demanding accountability, a tendency accentuated in the case of development aid, which is seen by the public as something non-vital in their daily affairs. If we want to proceed further than merely technical and financial accountability, many channels and funding sources (e.g. for development education) currently exist for supporting such endeavours. It is only through a concerted and energetic use of these that progress will be made toward a more active accountability providing openings for more effective and actual-as opposed to potential-participation on the part of civil society organisations and the general public.

A salient finding was that for accountability to deepen, diversify, and spread organizations' staffs' need to include specialized and appropriately trained personnel. If account- ability perspectives are to be widened, this implies not only technical training but also exposure to practices and approaches different to those used in Spanish development aid. Aid actors in the north and south should therefore incorporate into their human resource policies continuous staff 
development about innovative approaches to accountability. This could include participation in international forums, secondments of and exchanges between technical staff, training to international standards, and openings for forming alliances with universities and research centres.

Regarding field-level operations in the field, what seems most urgent is to stop thinking and acting in terms of projects and start thinking in terms of transformative and change processes over the long term. This has strong implications for accountability because it would shift the spotlight off accounting for funds or strategy objectives and onto the organizations with which alliances are formed and the network of relationships fostered as central resources for supporting complex change processes. Only by considering the diversity of the actors involved, the diversity of possible forms, and the role of power relationships will we be able to consistently construct new ideas, dynamics, and accountability practices.

Table 1 synthesises the key points of the section.

Table 1. Main features of accountability discourse identified when analysing accountability's meanings and practices 
NGOs, non-governmental organisations.

\begin{tabular}{|c|c|c|c|c|}
\hline \multicolumn{5}{|c|}{ Main features of discourse } \\
\hline & & $\begin{array}{c}\text { Governmental } \\
\text { actors }\end{array}$ & $\begin{array}{c}\text { Non-governmental } \\
\text { actors }\end{array}$ & All actors \\
\hline \multirow[t]{3}{*}{ Accountability } & Concept & $\begin{array}{l}\text { Some are reflecting on } \\
\text { mutual accountability, } \\
\text { but only as it relates to } \\
\text { public institutions. }\end{array}$ & $\begin{array}{l}\text { Greatly dependent on } \\
\text { criteria set by public } \\
\text { administration }\end{array}$ & $\begin{array}{l}\text { Limited to auditing or } \\
\text { financial control, lacking } \\
\text { any power analysis, } \\
\text { rendered to those } \\
\text { providing funds }\end{array}$ \\
\hline & Practices & $\begin{array}{l}\text { Asymmetric practices } \\
\text { between central and } \\
\text { autonomous/local } \\
\text { governments; social } \\
\text { accountability centred } \\
\text { on Spanish society and } \\
\text { information provision }\end{array}$ & $\begin{array}{l}\text { Few NGOs innovating } \\
\text { with social } \\
\text { accountability practices } \\
\text { that involve partners as } \\
\text { actors }\end{array}$ & $\begin{array}{l}\text { Mainly related to } \\
\text { transparency and } \\
\text { information provision }\end{array}$ \\
\hline & Barriers & $\begin{array}{l}\text { Gaps exist, associated } \\
\text { with the decentralised } \\
\text { political system and the } \\
\text { current mechanisms in } \\
\text { place. }\end{array}$ & $\begin{array}{l}\text { Fragmentation and } \\
\text { proliferation of NGOs } \\
\text { make coordination } \\
\text { more difficult. }\end{array}$ & $\begin{array}{l}\text { State coordinating bodies } \\
\text { not al ways capable of } \\
\text { delivering } \\
\text { accountability; NGOs } \\
\text { highly dependent on } \\
\text { govemment funds; } \\
\text { private interests and } \\
\text { clientelism obstruct } \\
\text { workings of aid councils; } \\
\text { conflict between aid and } \\
\text { other agenda; technical } \\
\text { barriers (resources, } \\
\text { project dependence etc); } \\
\text { scarcity of spaces for } \\
\text { reflection }\end{array}$ \\
\hline
\end{tabular}




\section{CONCLUSIONS}

This article has analysed the dominant types of accountability in the international aid sec- tor among both governmental and non-governmental actors. What we found in operation was a technical and financial model of accountability, largely isolated from contemporary international debates on the topic.

Dominant ways of exercising accountability are shaped by various factors, including the complex, highly decentralised governance model containing a myriad of actors, in which the responsibilities and competences of those who are accountable and those they are accountable to are either weakly defined, diluted, or, in the worst instances, an object of political confrontation. Another salient determinant is the lack of specific academic training in development that prevails among Spanish aid representatives at state level; the degree to which these can be considered development or aid professionals is well below what one might expect given the country's high volumes of aid, which have placed Spain in the sixth place in the international aid donor table. The examination of technical competences was not an objective of the study, nor were the staffing policies of the public and private organizations involved in development aid, but as experts on the subject have pointed out (Schulz, 2010), there is a serious problem of lack of professionalism in the sec- tor overall. We also observed that actors are not always coordinated and aid objectives sometimes enter into conflict with other objectives such as commercial or economic agenda or attempts to reap political benefits.

The development NGOs appear to be highly dependent on public funding at different levels and their accountability directed more at the funding bodies than at their southern partners or their own members, and there is little incentive for them to change this state of affairs. Add to this a Spanish society which generally shows little interest in the destination of public and private funds, and it becomes clear that changing this state of affairs will not be easy.

Although it was not one of our main objectives to find an explanation for this situation, we can offer some hypotheses. One of these is that the recentness of Spain's transition to democracy limits the degree of interest shown by its citizens in accountability and transparency. This hypothesis would require further investigation to substantiate it and to identify ways to improve accountability despite it, not only in the international aid sector but in all other public policy areas and in the actions of private organizations too.

We came across certain clues in our study as how the desirable changes might happen - interesting tendencies which, although they do not affect all the actors in the Spanish system, are visible in the work of organizations and institutions exposed to international discourses and forums, both governmental and non-governmental. Many of our interviewees made it clear that it is necessary to improve coordination among all the actors so that all concerned can take part in this debate.

The evaluation culture is also becoming more widespread in Spain, and interesting things are being learned from it that can contribute to improving 
accountability. The introduction of quality mechanisms may also encourage transparency and accountability. (However, it is important that quality does not get understood purely as financial account- ability, a tendency which, as we have pointed out above, can imply a reduction of effectiveness and efficiency of real aid accountability, diverting human and technical resources from the really important work.) This is associated with increasing professionalism in the sector, which would ensure that the human resources deployed in aid are well acquainted with the importance of accountability. It also seems to be necessary to improve informative actions directed at the Spanish public to convince people of the benefits of aid practices becoming more accountable.

Finally, because in this article we have shown a clear preference for an accountability model that goes beyond technical and financial information, we consider that the power relationships between all those who participate in development actions, in both north and south, should be made visible so that mechanisms can be adopted that foster greater horizontality in practice as well as in principle.

All these are important challenges that should be considered within the framework of the present economic crisis, which has had an enormous impact in Spain. In the coming years, we will doubtless see a considerable reduction in the funds devoted to ODA (Intermón Oxfam 2011). It remains to be seen whether these cuts have an effect on the quality of aid actions or whether they will be an encouragement to organizations and institutions to offer improved projects and incorporate not only technical accountability mechanisms, but also social and political ones.

\section{REFERENCES}

Bendell J. 2006. Debating NGO Accountability. Geneva, UN Non-Governmental Liaison (NGLS). http://www.un-ngls.org/orf/pdf/NGO_Accountability.pdf (accessed 2 December 2010).

Blagescu M, De Las Casas L, Lloyd R. 2005. Pathways to Accountability: The GAP Framework. One World Trust: London.

Chambers R, Pettit J. 2004. Shifting Power to Make a Difference. In Inclusive Aid, Groves L, Hinton R (eds). 137-162. Earthscan: London \& Sterling, VA.

Civil Society Voices For Better Aid. 2008. Civil Society Statement in Accra warns urgent action on aid. Statement, 1 september 2008. http://betteraid.org/ (accessed 20 October 2010).

Coordinadora Estatal de Cooperación al Desarrollo. 2008. Informe de la Coordinadora de ONG para el desarrollo España sobre el sector de las ONG 2008 (Report of the Spanish development NGO on the NGO sector 2008). Madrid: CONGDE. 
Corbetta P. 2003. Metodología y técnicas de investigación social (Social Research: Theories, Methods and Techniques). McGraw-Hill: Madrid.

De Renzio P, Mulley S. 2006. Promoting Mutual Accountability in Aid Relationships. ODI Briefing Paper. London: Overseas Development Institute.

Development Co-operation Directorate. 2010. Net ODA/GNI in 2009. http://www.oecd.org/ dataoecd/17/9/44981892.pdf (accessed 20 October 2010).

Droop J, Isenmanand P, Mlalazi B. 2008. Mutual accountability in aid effectiveness: International- level mechanisms. OPM briefing notes. Oxford: Oxford Policy Management.

Eyben R. 2008. Power, Mutual Accountability and Responsibility in the Practice of International Aid: A relational Approach. IDS Working Paper 305. Brighton: Institute of Development Studies.

Flick U, Kardorff E, Steinke I. 2004. A companion to qualitative research. Sage: London.

Goetz AM, Jenkins R. 2005. Reinventing accountability: making democracy work for human devel- opment. Hampshire \& New York: Palgrave Macmillan.

Harsh M, Mbatia P, Shrum W. 2010. Accountability and Inaction: NGOs and Resource Lodging. Development and Change 41 (2): 253-78.

Hayes L, Pereira J. 2008. Turning the Tables: Aid and accountability under the Paris framework, European Network on Debt and Development. http://www.eurodad.org/uploadedFiles/Whats_New/Reports/Turning_the_Tab les.pdf (accessed 3 December 2010).

Intermón Oxfam. (2011). "La calidad de la ayuda 2010”, Editorial Intermón Oxfam http://www. intermonoxfam.org/UnidadesInformacion/anexos/12115/110209_realidadayu da.pdf (accessed 27th June 2010).

ISG. 2007. From Paris 2005 to Accra 2008: Will Aid Become More Accountable and Effective? A Critical Approach to the Aid Effectiveness Agenda. International CSO Steering Group draft position paper. CSO Parallel Process to the Ghana High Level Forum Network.

Jordan L, Van Tuijl P. 2006. Rights and Responsibilities in the Political Landscape of NGO Accountability: Introduction and Overview. In NGO Accountability, Jordan L, Van Tuijl P (eds). 3-20. Earthscan: London \& Sterling, VA.

Litovsky A, Macgillivray A. 2007. Development as Accountability. AccountAbility: London. Meyer S. 2007. La cooperación española para el desarrollo: ¿Aspiraciones hechas realidad? (The Spanish development aid: 
Aspirations become true?). FRIDE Working paper 40. Madrid: Fundación para las Relaciones Internacionales y el Diálogo Exterior.

Ministerio de Asuntos Exteriores y Cooperación. 2009. Seguimiento PACI 2008 (PACI Monitoring

2008). http://www.maec.es/es/MenuPpal/CooperacionInternacional/Publicacionesydocumen tacion/Documents/2008Seg\%20PACI.pdf (accessed 3 December 2010).

Montiel A. 2007. Globalización, subdesarrollo y responsabilidad internacional. El papel de la coop- eración descentralizada en el desarrollo humano global (Globalization, underdevelopment and international responsibility. The role of decentralized cooperation in the global human development). La cooperación técnica para el desarrollo (Technical development aid) 16: 53-82.

Newell P. 2006. Taking accountability into account: The debate so far. In Rights, Resources and the Politics of Accountability, Newell P, Wheeler J (eds). 3758. Zed Books: London.

Newell P, Bellour S. 2002. Mapping accountability: origins, contexts and implications for develop- ment. IDS Working Paper 168. Brighton: Institute of Development Studies.

OECD. 2005. Paris Declaration on Aid Effectiveness. Statement in the Second High Level Forum on Aid Effectiveness, Paris (2 March).

OECD. 2007. 2006 Survey on Monitoring the Paris Declaration. Organization for Economic Co-operation and Development: Paris.

OECD. 2008. Accra Agenda for Action. Statement in the Third High Level Forum on Aid Effectiveness, Accra (4 September).

Peruzzotti E. 2006. Civil Society, Representation and Accountability: Restating Current Debates on the Representativeness and Accountability of Civic Associations. In NGO Accountability, Jordan L, Van Tuijl P (eds). 43-58. Earthscan: London \& Sterling, VA.

Piron LH. 2004. Rights-Based Approaches to Social Protection. ODI background paper. London: Overseas Development Institute.

Sánchez A. 2007. La cooperación descentralizada desde los municipios (Decentralized cooperation from the municipalities). La cooperación técnica para el desarrollo (Technical development aid) 16: 155-80.

Schulz N. 2010. Spanish development policies: the obstacles to progress, FRIDE Policy Brief 30. Madrid: Fundación para las Relaciones Internacionales y el Diálogo Exterior.

Tezanos S. 2008. Cooperación para el Desarrollo. Asignación geográfica de la ayuda española (Development Cooperation. Geographical allocation of Spanish aid). Madrid: Editorial Biblioteca Nueva. 
Valles M. 1996. Técnicas cualitativas de investigación social (Qualitative social research techniques). Madrid: Editorial Síntesis.

Wood B, Kabell D, Muwanga N, Sagasti F. 2008. Evaluation of the Implementation of the Paris Declaration: phase one: synthesis report. Ministry of Foreign Affairs of Denmark: Copenhagen. 